\title{
Analysis of Chemical Properties and Antioxidant Activity of Sambiloto (Andrographis paniculata Nees.) Leaf Tea Formula as a Functional Drink in Preventing Coronavirus Diseases and Degenerative Diseases
}

\author{
Siti Ika Fitrasyah ${ }^{1 *}$, Ariani Ariani ${ }^{1}$, Nurdin Rahman ${ }^{1}$, Nurulfuadi Nurulfuadi ${ }^{1}$, Ummu Aiman ${ }^{1}$, Devi Nadila ${ }^{1}$, Fendi Pradana ${ }^{1}$, \\ Aulia Rakhman ${ }^{1}$, Diah Ayu Hartini ${ }^{2}$ \\ ${ }^{1}$ Department of Nutrition, Tadulako University, City of Palu, Indonesia; ${ }^{2}$ Department of Nutrition, Poltekkes Kemenkes Palu, City \\ of Palu, Indonesia
}

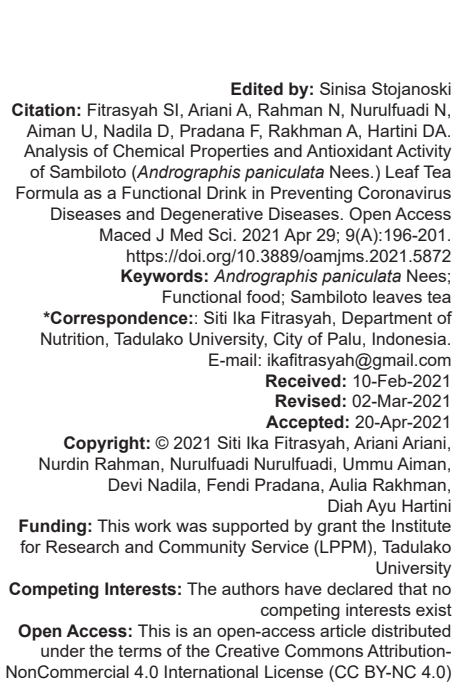

\begin{abstract}
AIM: The purpose of this study was to develop a tea formula of sambiloto leaves, analyzed the chemical properties (polyphenols, tannins, water, extracts in water, total ash, water soluble ash, water-insoluble ash, insoluble acid ash and water-soluble ash alkalinity) as well as the antioxidant capacity of the formula.

METHODS: This research was divided into two stages. The first stage was the formulation of sambiloto leaves tea and the second stage was the analysis of chemical properties (levels of polyphenols, tannins, water, extracts water total ash, water soluble ash, water-insoluble ash, insoluble acid ash, and water soluble ash alkalinity) and antioxidant capacity analysis. The analysis was carried out on all of the sambiloto leaves tea formulas to determine the effect of the formulations on chemical properties and antioxidant capacity. This study used Microsoft Excel 2013 in data processing management.

RESULTS: The highest extract water was at F4, and the lowest was at F1. Based on the analysis, the formula of sambiloto leaves tea was in the range of $1.026-1.734 \%$. Of all the formulas that have been prepared, sambiloto leaves tea formula F1 was obtained the best chemical and antioxidant properties among all formulas, which were composed of $100 \%$ sambiloto leaves, $5 \%$ honey, and $45 \%$ dates.

CONCLUSION: Sambiloto leaves have good antioxidant activity and can be used as a drink in the form of an infusion, such as tea. The result of brewing the sambiloto tea formula has faded green color. The polyphenol content
\end{abstract} of the sambiloto leaves tea formula still did not meet the Indonesia National Standard ( $\geq 5.2 \%)$, was $1.5-3.1 \%$.

\section{Introduction}

Antioxidants, in this case, may provide benefits to the body's immune system, which inhibit free radicals and become an inhibitor of lipid peroxidation to prevent oxidative stress [1]. Tea is one of the most widely consumed drinks by Indonesians, which is produced from the tea (Camellia sinensis) leaves. Green tea has the highest antioxidant activity, followed by oolong and black teas [2]. Tea has health benefits due to the various active components known as polyphenols in it. Tea found high in antioxidants and minerals [3]. One of the potent antioxidants in tea is epigalo-catechins and quercetin, which are derivatives of catechins [4].

In Indonesia, one of the popular medicinal plants is sambiloto (Andrographis paniculata Nees.) [5], which has the potential to be developed into alternative therapies in increasing the body's immune system. The active compounds contained in Sambiloto act as immunomodulators, including deoxyandrographolide, andrographolide, neoandrographolide,

diterpenoids, flavonoids [6], $\beta$-sitosterol, stigmasterol [7], and polyphenols [8]. Sambiloto leaves potentially as an immunomodulator, immunostimulator, and immunosuppressor agents [6].

Sambiloto leaves tea is a mixture of green tea leaves with sambiloto leaves. The aroma of sambiloto leaves is relatively neutral with a very bitter taste [9] letting it unpopular among society. Several diseases may be cured by using sambiloto such as influenza, lung abscess, pneumonia, inflammation of the airways, fever, pulmonary tuberculosis, shortness of breath, lung tumors, and others [10]. Furthermore, research shows that green tea is beneficial for preventing cancer, osteoporosis, cardiovascular disease, and 
atherosclerosis [11]. To improve the taste of sambiloto leaves and food diversity, the researchers wanted to formulate a sambiloto leaves tea sweetened with natural sweeteners derived from dates and/or honey.

The purpose of this study was to develop a tea formulation of sambiloto leaves and analyzed the chemical properties (levels of polyphenols, tannins, water, extracts water, total ash, water-soluble ash, water-insoluble ash, insoluble acid ash, and watersoluble ash alkalinity) as well as the antioxidant capacity of the products

\section{Methods}

\section{Materials}

The materials used consisted of the main ingredients and supporting materials. The primary raw materials in this study were the leaves of sambiloto (A. paniculata Nees.) obtained from the traditional market in Palu City, honey, and dried dates which can be obtained in food shops in Palu City. Supporting materials used were hot water, aluminum foil, tissue, filter paper, $85 \%$ and $90 \%$ ethanol, 2,2-diphenyl-1picrylhydrazyl (DPPH) solution, $100 \mathrm{ppm}$ standard solution or gallic acid solution (15 g formula and $15 \mathrm{~mL}$ ethanol), distilled water reagent, and $1.5 \mathrm{~mL}$ Sodium Carbonate $\left(\mathrm{Na}_{2} \mathrm{CO}_{3}\right) 20 \%$.

\section{Tools}

The equipment used in this study consisted of two groups, namely, tools for processing sambiloto tea and tools for chemical analysis. The tools used for the producing of sambiloto leaves tea were an oven, aluminum pan, cutting board, basin, and bucket. The tools used for chemical analysis were rotary vacuum evaporator, oven, desiccator, orbital shaker, shaker, measuring cup, dropper, Erlenmeyer, watch glass, measuring flask, beaker, test tube rack, glass funnel, test tube, balance analytic, spatula, kiln, crucible clamp, and ultraviolet (UV) Vis Spectrophotometer.

\section{Methods}

This research was divided into two stages. The first stage was the formulation of sambiloto leaves tea and the second stage was the analysis of chemical properties (levels of polyphenols, tannins, water, extracts water, total ash, water soluble ash, waterinsoluble ash, insoluble acid ash, and water soluble ash alkalinity) and antioxidant capacity analysis. The analysis was carried out on all of the sambiloto leaves tea formulas to determine the effect of the formulations on chemical properties and antioxidant capacity.

\section{Formulation}

Before the formulation was carried out, the raw materials were prepared first, such as picking fresh sambiloto leaves without defects and dark green, then the fresh bitter leaves were sorted, separated from the stems, stalks, and yellow leaves with white spots or damaged. A withering process was carried out aimed to reduce the moisture content in the fresh sambiloto leaves so the drying process occurs more quickly and no water was carried away when put into the oven where the withering time was around $24 \mathrm{~h}$ with a temperature of $30^{\circ} \mathrm{C}$. The withered sambiloto leaves were then chopped into small pieces to speed up the drying process. After chopping was carried out, sambiloto leaves were weighed and used about $100 \mathrm{~g}$ per treatment. Drying was done using an oven dryer at a temperature of $60^{\circ} \mathrm{C}$ for $60 \mathrm{~min}$. The temperature of $60^{\circ} \mathrm{C}$ was applied that the best treatment of sambiloto tea was drying temperature of $60^{\circ} \mathrm{C}$ with water content $(8.16 \%)$, ash content $(8.04 \%)$, antioxidant activity $(78.29 \%)$, water-soluble extract content $(41,93 \%)$ as well as aroma (neutral and slight distinctive aroma of sambiloto leaves), taste (dislike and very bitter), and color (neutral and brownish yellow) [9]. The brewing process was carried out by taking $3 \mathrm{~g}$ of dried sambiloto leaves and $200 \mathrm{ml}$ of hot water $\left(\mathrm{T} 90^{\circ} \mathrm{C}\right)$ for $2 \mathrm{~min}$ because the brewing time and temperature can produce the best tea brewing [12], [13] and is preferred by the majority of Asian population who use the formulation from the study [14], [15]. Then finally, honey or dates were added as a natural sweetener for each treatment. The formulation of sambiloto leaves tea is shown in Table 1.

Table 1: Sambiloto tea formulations

\begin{tabular}{llll}
\hline Formula & Sambiloto leaves $(\%)$ & Honey $(\%)$ & Dates $(\%)$ \\
\hline F1 & 100 & 5 & 45 \\
F2 & 75 & 10 & 55 \\
F3 & 50 & 15 & 65 \\
F4 & 25 & 20 & 75 \\
\hline
\end{tabular}

\section{Chemical analysis}

The chemical properties analyzed were polyphenol content, water content, extract water, and total ash content. The antioxidant capacity analysis was performed using the DPPH method [16]. Data analysis is descriptive analysis using Ms. Excel.

\section{Results}

Chemical properties analysis was carried out for all the sambiloto leaves formulas. Analysis of chemical properties of sambiloto leaves tea products consisted of an analysis of polyphenol content, tannins, water, water extract, total ash, water soluble ash, water-insoluble ash, insoluble acid ash, and water-soluble ash alkalinity. 
Besides, sambiloto leaves tea was also analyzed for its antioxidant capacity. The results of the chemical properties analysis in this study are shown in Table 2.

Table 2: Chemical properties of sambiloto leaves tea

\begin{tabular}{lllll}
\hline Parameters & \multicolumn{3}{l}{ Sambiloto tea formula } \\
\cline { 2 - 5 } & F1 & F2 & F3 & F4 \\
\hline Polyphenol total (\%) & 3.100 & 2.720 & 1.920 & 1.500 \\
Tannin total (\%) & 0.184 & 0.375 & 0.454 & 0.596 \\
Water (\%) & 14.005 & 14.974 & 15.759 & 16.821 \\
Water extract (\%) & 43.182 & 45.085 & 48.189 & 51.659 \\
Total ash (\%) & 8.843 & 6.697 & 5.063 & 4.626 \\
Water-soluble ash (\%) & 48.486 & 52.412 & 60.014 & 63.030 \\
Water-insoluble ash (\%) & 5.604 & 3.551 & 4.399 & 2.824 \\
Acid insoluble ash (\%) & 0.287 & 0.245 & 0.221 & 0.212 \\
The alkalinity of water soluble ash (\%) & 1.734 & 1.157 & 1.046 & 1.026 \\
\hline F1: 100\% sambiloto leaves, 5\% honey, and 45\% dates, F2: 75\% sambiloto leaves, 10\% honey, and 55\% \\
dates, F3: 50\% sambiloto leaves, 15\% honey, and 65\% dates, F4: 25\% sambiloto leaves, 20\% honey, and \\
75\% dates.
\end{tabular}

\section{Discussion}

\section{Polyphenol level}

The polyphenol content in the original sambiloto leaves tea was low (1.5-3.1\%) with the highest level was $\mathrm{F} 1$, and the lowest was F4. The polyphenol content (w/w) in the original sambiloto leaves tea was quite far below the standard set by Indonesia National Standard (SNI), at least $5.2 \%$ [17]. Based on the polyphenol content test, none of the formulas exceeded the standards set by SNI. The higher the sambiloto leaves content in the formula, the higher the polyphenol content obtained.

Polyphenols are natural compounds found mostly in fruits, vegetables, cereals, and beverages [18]. Polyphenols can be classified into major classes including phenolic acids, flavonoids, stilbenes, and lignans. However, food matrices generally contain complex mixtures of these compounds, at variable concentrations, which may not be well characterized [19]. Polyphenols consist of several sub-classes, including flavonols, flavones, flavanones, anthocyanidins, catechins, and biflavan. Over the last few decades, polyphenols in plants is considered potential in providing prevention from various diseases. High consumption of polyphenols can provide prevention from various chronic diseases such as cancer, diabetes, cardiovascular, and aging [18]. Some polyphenols are specific for certain foods (i.e., flavanones in citrus fruits, isoflavones in soybeans, and phloridzin in apples); whereas others, such as quercetin are found in all plant products such as fruit, vegetables, cereals, legumes, tea, and wine [14]. Flavonoids can induce a human protective enzyme system. The protective effect of flavonoids against many infectious diseases (bacteria and viruses) and degenerative diseases was including cardiovascular disease, cancer, and other age-related diseases. Flavonoids also act as secondary antioxidant defense systems in plant tissues exposed to different abiotic and biotic stresses. Flavonoids are located in the nucleus of mesophyll cells, and the generation center of reactive oxygen species [21]. It was found that the polyphenol content in sambiloto leaves was $493.7 \pm$ $10.0 \mathrm{mg} \mathrm{TAE} / \mathrm{g}$ [22].

Tannins are bitter plant polyphenols that bind and precipitate or shrink to the protein. The astringency of tannins causes a dry, shrivelled taste in the mouth following consumption of red wine, strong teas, or raw fruit [23]. The maximum tannin content in food ingredients set by the acceptable daily intake (ADI) is $560 \mathrm{mg} / \mathrm{kg}$ body weight per day or in pure tea leaves the tannin content ranges from 5\% to 15\% [24]. From this research, it was found that the tannin content was 0.184-0.596\%, where F4 owned the highest total tannin content, and the lowest was at F1. The requirements for normal tannin standards are already mentioned in the fourth sentence of this paragraph "The maximum tannin content in food ingredients set by the ADI is 560 $\mathrm{mg} / \mathrm{kg}$ body weight per day or in pure tea leaves the tannin content ranges from $5 \%$ to $15 \%$. Tannins are categorized as non-nutrient, but in small amounts, it can be beneficial for health. In some tea preparations, this tannin content is maintained in a certain amount in order to provide functional value.

\section{Water content}

The results of the water content analysis showed that the water content of the sambiloto leaves tea ranged from $14.005 \%$ to $16.821 \%$ with the highest level was F4, and the lowest was F1. The water content (w/w) of all formulas did not comply the SNI 3836: 2013 standard (maximum water content of $8 \%$ for packaged dry tea) [17].

\section{Water extract}

Following Table 2, the highest extract water was at F4, and the lowest was at F1. Extract water (w/w) in all formulas of sambiloto leaves tea had a higher level than commercial dry tea in general, which has a minimum extract content of 32\% according to SNI 3836: 2013 [17]. The water extract in this study was higher than the previous study, which obtained $30.37 \pm 2.63$ [25].

The water extract describes the compounds or ingredients survive in water. Sambiloto plants contain flavonoids/flavones in all parts of the plant. These flavonoids are the most common and widespread group of plant phenolic compounds, occurring in almost all parts of plants, especially photosynthetic plant cells. Furthermore, solubility plays a role in the therapeutic efficacy of flavonoids. The low solubility of flavonoids in water often creates problems for their medicinal applications, then the sambiloto plant better to not heated in water for long term [21], [26].

\section{Total ash}

Determination of the total ash content can be used to determine the processing quality, knowing the 
types of ingredients used, determining the parameters of the nutritional value of a food ingredient. Of the four formulas, only F1 containing a total ash content (w/w) was higher than those recommended by $\mathrm{SNI} 3836$ : 2013, a maximum of $8 \%$ [17]. F1 was the highest total ash content, while F4 was the lowest.

\section{Water-soluble ash and water-insoluble ash}

Based on the analysis results, the four formulas contain water-soluble ash content (w/w) higher than that SNI 3836: 2013, at least 45\% (range 48.486-63.030\%) [17] with the highest level was F4, and the lowest was F1. This illustrated that the sambiloto leaves tea formula had a higher water soluble ash content than tea in general. Increasing the water soluble ash content will indirectly reduce the water-insoluble ash content in tea. In the analysis, it was found that the water-insoluble ash content was in the range of 2.824-5.604 with the highest concentration in F1 and the lowest at F4.

\section{Acid-insoluble ash}

According to the analysis results, the four formulas have acid insoluble ash content (w/w) which was lower than the limit determined by SNI (maximum $1 \%$ ). Based on the analysis results, the sambiloto leaves tea formula was $0.212-0.287 \%$ with the lowest levels at F4 and the highest at F1. Determination of acid-insoluble ash content is closely related to the mineral content contained in a material, the purity, and cleanliness of the material [27].

\section{The alkalinity of water soluble ash}

Table 2 shows the four formulas have alkalinity levels of water-soluble ash (as $\mathrm{KOH})(\mathrm{w} / \mathrm{w})$ which were lower than the limits determined by SNI (1-3\%). Based on the analysis, the formula of sambiloto leaves tea was in the range of $1.026-1.734 \%$. F1 was the highest ash alkalinity, and the lowest was F4. Ash alkalinity is a parameter in differentiating between pure food and synthetic food. Ash from vegetables and fruits are classified alkaline ( $\mathrm{Ca}, \mathrm{Mg}, \mathrm{K}$, and $\mathrm{Na}$ ), in contrast, meat, and some cereals classified acidic ( $\mathrm{P}, \mathrm{S}$, and $\mathrm{Cl})$ [28]. Ash alkalinity could be a quality index of fruit products [29].

\section{Antioxidant capacity}

The antioxidant activity determination using this method can be observed based on the loss of purple color due to the reduction of DPPH by antioxidants. The color intensity of the test solution was measured by UV-Vis spectrophotometry at a wavelength of about $520 \mathrm{~nm}$. The percentage inhibition is substituted in the linear equation and then interpreted as $I_{50}$ [30]. The inhibitory percentage is the ratio between the difference of absorbance of the blank and sample. The percentage of inhibition is used to determine the percentage of resistance of a substance to free radical compounds. $\mathrm{IC}_{50}$ is defined as the amount of antioxidant required to reduce the initial DPPH concentration by $50 \%$. BrandWilliams et al. in 1995 introduced this parameter. This method has the advantage of being more straightforward, and the analysis time is fast [31]. The percentage of free-radical inhibition of sambiloto leaves tea formula is shown in Table 3. It can be seen that the highest average inhibition was found in F1, while the lowest was in F3.

Table 3: Free-radical inhibitory percentage of sambiloto leaves tea

\begin{tabular}{lll}
\hline Formula & Inhibitory percentage & Average inhibitory percentage \\
\hline F1 & 41.5 & 46.2 \\
& 43.8 & \\
& 46.3 & \\
& 48.8 & 45.7 \\
F2 & 50.4 & \\
& 41.8 & \\
& 43.4 & 44.9 \\
& 45.8 & \\
F3 & 47.8 & \\
& 49.7 & 45.4 \\
& 41.3 & \\
& 43.3 & \\
F4 & 45.1 & \\
& 46.5 & \\
& 48.5 & \\
& 41.7 & \\
& 44.0 & 45.4 \\
F1: $100 \%$ sambiloto leaves, $5 \%$ honey, and $45 \%$ dates, F2: $75 \%$ sambiloto leaves, $10 \%$ honey, and $55 \%$ \\
dates, F3: 50\% sambiloto leaves, $15 \%$ honey, and $65 \%$ dates, F4: $25 \%$ sambiloto leaves, $20 \%$ honey, and \\
\end{tabular}

The antioxidant activity was expressed in $\mathrm{IC}_{50}$ : the smaller $I_{50}$ value, the higher of antioxidant activity. Compounds are known to be categorized very strong antioxidants if the $\mathrm{IC}_{50}$ value was $<50 \mu \mathrm{g} / \mathrm{ml}$, strong if the $\mathrm{IC}_{50}$ value was between 50 and $100 \mu \mathrm{g} / \mathrm{ml}$, moderate if the $\mathrm{IC}_{50}$ value ranges from 100 to $150 \mu \mathrm{g} / \mathrm{ml}$, and weak if the $I_{50}$ value ranges from 150 to $200 \mu \mathrm{g} / \mathrm{ml}$ [32]. The antioxidant capacity of the sambiloto leaves tea formula is shown in Table 4. Based on the table below, the formula with the highest antioxidant capacity was found in F1 with the strong antioxidant category, and F2, F3, and F4 categorized moderate antioxidant.

Table 4: Antioxidant capacity of sambiloto leaves tea formula

\begin{tabular}{lll}
\hline Formula & Antioxidant capacity in $\mathrm{IC}_{50}(\mu \mathrm{g} / \mathrm{ml})$ & Category \\
\hline F1 & 94.0 & Active \\
F2 & 103.3 & Moderate \\
F3 & 117.7 & Moderate \\
F4 & 112.8 & Moderate \\
\hline F1: $100 \%$ sambiloto leaves, $5 \%$ honey, and $45 \%$ dates, F2: $75 \%$ sambiloto leaves, $10 \%$ honey, and $55 \%$ \\
dates, F3: 50\% sambiloto leaves, $15 \%$ honey, and $65 \%$ dates, $\mathrm{F} 4: 25 \%$ sambiloto leaves, $20 \%$ honey, and \\
$75 \%$ dates
\end{tabular}

Testing the antioxidantactivity ofandrographolide isolates from sambiloto extract with ascorbic acid standard showed that the antioxidant activity of andrographolide has an $\mathrm{IC}_{50}$ value of $6 \mu \mathrm{g} / \mathrm{ml}$, not much different from the standard IC ${ }_{50}$ of ascorbic acid, was $5.0 \mu \mathrm{g} / \mathrm{ml}$ [33]. In the fraction of sambiloto contains andrographolide content. Antioxidant activity of the herb sambiloto is due to the content of flavonoids and andrographolide. The ethanol extract of sambiloto had an $\mathrm{IC}_{50}$ value of $792.126 \mu \mathrm{g} / \mathrm{ml}$, while the quercetin standard had an $\mathrm{IC}_{50}$ value of 3.403 $\mu \mathrm{g} / \mathrm{ml}$ [34]. The content of flavonoids and andrographolid in sambiloto herb let this herb to have antioxidant activity. 


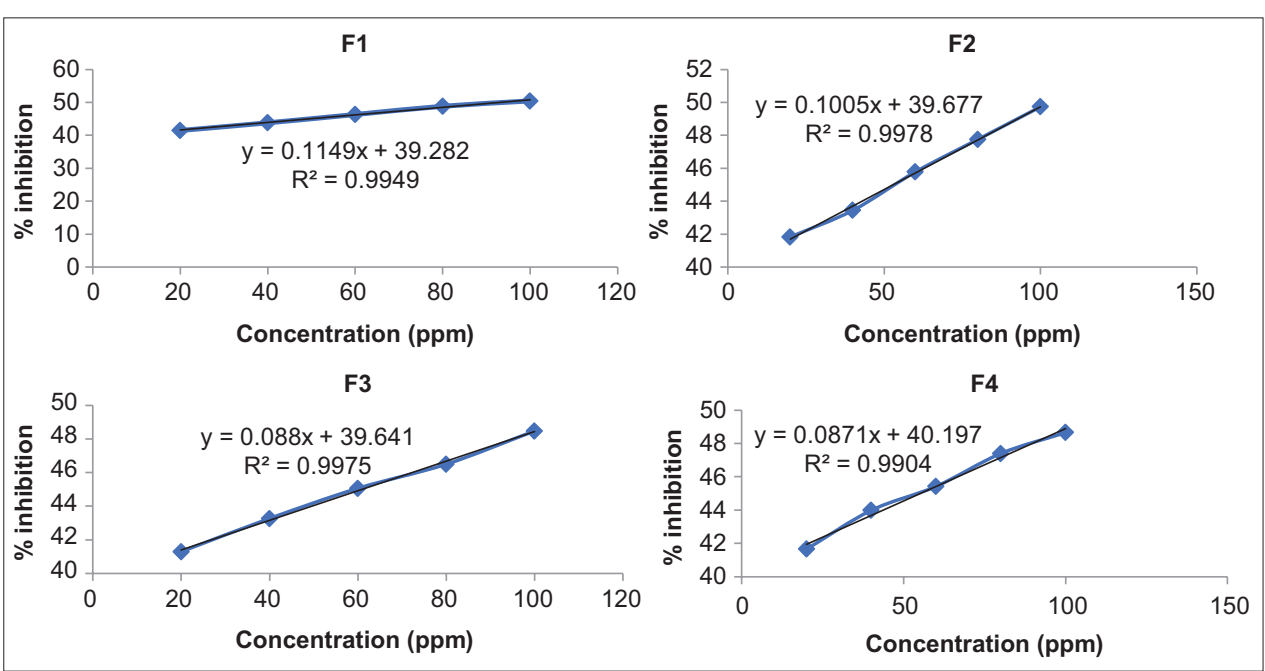

Figure 1: Graph of free-radical inhibition of sambiloto leaves tea

Thus, it revealed the herb sambiloto potentially to be developed as an antioxidant.

Figure 1 shows the relationship between concentration and percentage of inhibition, which uses 5 concentration series, namely $20,40,60,80$ and 100 ppm. The $\mathrm{x}$-axis shows the concentration (ppm) and the $y$-axis shows the percentage value of inhibition (\%). The regression equation shown on the graph for $\mathrm{F} 1$ is $\mathrm{y}=$ $0.1149 x+39.282, R^{2}=0.9949$; the equation $F 2$ is $y=$ $0.1005 x+39.677, R^{2}=0.9978$; the equation F3 is $y=$ $0.088 x+39.641, R^{2}=0.9975$; and the equation F4 is $y=0.0871 x+40.197, R^{2}=0.9904$. For the regression equation where $\mathrm{y}=50$.

\section{Conclusion}

Sambiloto leaves have good antioxidant activity and can be used as a drink in the form of an infusion, such as tea. The result of brewing the sambiloto tea formula has faded green color. The polyphenol content of the sambiloto leaves tea formula still did not meet the SNI standard ( $\geq 5.2 \%)$, was $1.5-3.1 \%$. Of all the formulas that have been prepared, sambiloto leaves tea formula F1 was obtained the best chemical and antioxidant properties among all formulas, which were composed of $100 \%$ sambiloto leaves, $5 \%$ honey, and $45 \%$ dates.

\section{Acknowledgments}

The author would like to thank the Institute for Research and Community Service (LPPM), Tadulako University, for providing this research grant. Also, to all researchers contribute to completing this research until the final stage of writing this article.

\section{References}

1. Kurutas EB. The importance of antioxidants which play the role in cellular response against oxidative/nitrosative stress: Current state. Nutr J. 2015;15(1):71. https://doi.org/10.1186/ s12937-016-0186-5

PMid:27456681

2. Yashin A, Yashin Y, Nemzer B. Determination of antioxidant activity in tea extracts, and their total antioxidant content. Am J Biomed Sci. 2011;3(4):322-35. https://doi.org/10.5099/ aj110400322

3. Smith K. World Atlas of Tea: From Tea Leaf to The Cup, The World's Teas Explored and Enjoyed. United Kingdom: Hachette UK; 2016.

4. Lima GP, Vianello F, Corrêa CR, da Silva Campos RA Borguini MG. Polyphenols in fruits and vegetables and its effect on human health. Food Nutr Sci. 2014;5(11):1065-82. https:// doi.org/10.4236/fns.2014.511117

5. Salim Z, Munadi E. Info Komoditi Tanaman Obat. Badan Pengkajian dan Pengembangan Perdagangan Kementerian Perdagangan Republik Indonesia; 2017.

6. Alkandahri MY, Subarnas A, Berbudi A. Review: Aktivitas immunomodulator tanaman sambiloto (Andrographis paniculata nees). Farmaka. 2018;16(3):16-21.

7. Tan MC, Oyong GG, Shen CC, Ragasa CY. Chemica constituents of Andrographis paniculata (Burm.f.) Nees. Int J Pharmacog Phytochem Res. 2016;8(8):1398-402.

8. Chao WW, Lin BF. Isolation and identification of bioactive compounds in Andrographis paniculata (Chuanxinlian). Chin Med. 2010;5(1):17. https://doi.org/10.1186/1749-8546-5-17

9. Patin EW, Zaini MA, Sulastri Y. Pengaruh variasi suhu pengeringan terhadap sifat fisiko kimia teh daun sambiloto (Andrographis paniculata). Pro Food. 2018;4(1):251-8. https:// doi.org/10.31764/agrotek.v5i1.225

10. Nanotech Herbal Indonesia, Manfaat Dan Khasiat Daun Sambiloto Untuk Kesehatan; 2014. Available from: https://www. biofarmaka.ipb.ac.id. [Last access on 2020 Dec 20].

11. Cabrera C, Artacho R, Gimenez R. Beneficial effect of green tea. J Am Coll Nutr. 2006;25(2):79-99.

12. Hary KA. Formulasi Teh Daun Sirih Merah (Piper Crocatum) Sebagai Minuman Fungsional; 2017

13. Heiss ML. Green Tea, the Harvard Common Press (RHYW) 2006.

14. Aji PS, Anandito RB, Nurhartadi E. Penambahan berbagai jenis 
madu sebagai alternatif pemanis minuman sari buah naga putih (Hylocereus undatus). Biofarmasi. 2013;11(1):13-8.

15. Simatupang LF, Nainggolan RJ, Nurminah M. The Effect of Ratio of Dates Juice (Phoenix dactylifera) With Kecombrang Juice (Etlingera elatior) and The Addition of Aren Sugar on The Quality of Kumbrang Juice Drink). J Rekayasa Pangan Pert. 2018;6(2):264-72. https://doi.org/10.21111/dnj.v2i1.1982

16. Kubo I, Masuoka N, Xiao P, Haraguchi H. Antioxidant activity of dodecyl gallate. J Agric Food Chem. 2002;50(12):3533-9. https://doi.org/10.1021/jf011250h PMid:12033824

17. Badan Standardisasi Nasional Indonesia (BSN). Teh Kering Dalam Kemasan: SNI No. 3836:2013. Indonesia: Badan Standardisasi Nasional; 2013. https://doi.org/10.31153/ js.v15i2.114

18. Pandey KB, Rizvi SI. Plant polyphenols as dietary antioxidants in human health and disease. Oxid Med Cell Longev. 2009;2(5):270-8. https://doi.org/10.3390/nu9091044 PMid:20716914

19. Baião $D D$, de Freitas $C S$, Gomes LP, da Silva D, Correa AC, Pereira PR, et al. Polyphenols from root, tubercles and grains cropped in Brazil: Chemical and nutritional characterization and their effects on human health and diseases. Nutrients. 2017;9(9):1044.

PMid:28930173

20. D’Archivio M, Filesi C, Varì R, Scazzocchio $B$, Masella $R$. Bioavailability of the polyphenols: Status and controversies. Int J Mol Sci. 2010;11(4):1321-42. https://doi.org/10.3390/ ijms 11041321

PMid:20480022

21. Kumar S, Pandey AK. Chemistry and biological activities of flavonoids: An overview. ScientificWorldJournal. 2013;2013:162750.

PMid:24470791

22. Nurcholis W, Priosoeryanto BP, Purwakusumah ED, Katayama T, Suzuki T. Antioxidant, cytotoxic activities and total phenolic content of four indonesian medicinal plants. J Kimia Valensi. 2012;2(4). https://doi.org/10.15408/jkv.v2i4.267

23. McGee H. On Food and Cooking: The Science and Lore of the Kitchen, Scribner; 2007. https://www.search.ebscohost. com/login.aspx? direct=true\& scope $=$ site \&db=nlebk $\& d b=n l a b k \& a n=1965177$. [Last accessed on 2020 Nov 22].

24. Fajrina A, Jubahar J, Sabirin S. Determination of Tannin Levels in
Tea Bags Circulating in the Market by UV-Vis Spectrophotometry. J Farmasi Higea. J Farmasi Higea. 2016;8(2):133-42. https:// doi.org/10.36656/jpfh.v3i1.313

25. Ameh SJ, Obodozie OO, Inyang US, Abubakar MS, Garba M. Quality control tests on Andrographis paniculata nees (Family: Acanthaceae)-an Indian 'wonder' plant grown in Nigeria. Trop J Pharm Res. 2010;9(4):387-94. https://doi.org/10.4314/tjpr. v9i4.58937

26. Okhuarobo A, Falodun JE, Erharuyi O, Imieje V, Falodun A, Langer P. Harnessing the medicinal properties of Andrographis paniculata for diseases and beyond: Areview of its phytochemistry and pharmacology. Asian Pac J Trop Dis. 2014;4(3):213-22. https://doi.org/10.1016/s2222-1808(14)60509-0

27. Husna NE. Leubiem fish (Canthidermis maculatus) jerky with variation of production methods, type of sugar, and drying methods. J Teknol Industri Pertnian Indones. 2014;6(3):76-81. https://doi.org/10.17969/jtipi.v6i3.2316.

28. Schwalfenberg GK. The alkaline diet: Is there evidence that an alkaline $\mathrm{pH}$ diet benefits health? J Environ Public Health. 2012;2012:727630.https://doi.org/10.1155/2012/727630 PMid:22013455

29. Nielsen SS. Food Analysis (Food Science Text Series). $4^{\text {th }}$ ed Berlin: Springer; 2010.

30. Kedare SB, Singh RP. Genesis and development of DPPH method of antioxidant assay. J Food Sci Technol. 2011;48(4):41222. https://doi.org/10.1007/s13197-011-0251-1 PMid:23572765

31. Nariya P, Nariya M, Shukla V, Acharya R, Bhalodia N. In vitro evaluation of antioxidant activity of Cordia dichotoma (Forst f.) bark. AYU. 2013;34(1):124-8. https://doi. org/10.4103/0974-8520.115451 PMid:24049418

32. Jun M, Fu HY, Hong J, Wan X, Yang CS, Ho CT. Comparison of antioxidant activities of isoflavones from kudzu root (Pueraria lobata Ohwi). J Food Sci. 2003;68(6):2117-22. https://doi. org/10.1111/j.1365-2621.2003.tb07029.x

33. Saranya $P$, Geetha A, Selvamathy SM. The antioxidant and $\mathrm{H}+\mathrm{K}+$ atpase inhibitory effect of Andrographis paniculata and andrographolide-in vitro and in vivo studies. Pharmacologyonline. 2010;1:356-76.

34. Rais IR. Aktivitas antioksidan ekstrak Andrographis paniculata (Burm.f.) ness dengan dua perbedaan penguapan. Pharmaciana. 2016;6(1):95-100. https://doi.org/10.12928/ pharmaciana.v6i1.3226 